American Journal of Applied Sciences 8 (10): 962-966, 2011

ISSN 1546-9239

(C) 2011 Science Publications

\title{
Bioethics Principles in the Teaching of Climate Change
}

\author{
${ }^{1}$ Ravichandran Moorthy, ${ }^{2}$ Er Ah Choy, \\ ${ }^{2}$ Sivapalan Selvadurai and ${ }^{2}$ Novel Lyndon \\ ${ }^{1}$ School of History, Politics and Strategy, \\ ${ }^{2}$ School of Social, Development and Environmental Studies, \\ Faculty of Social Sciences and Humanities, \\ University Kebangsaan Malaysia, 43000 Bangi, Selangor, Malaysia
}

\begin{abstract}
Problem statement: Bioethics is the philosophical study of the ethical controversies about humans and his environment. Bioethicists are concerned with the ethical questions that arise in the relationships among life sciences, biotechnology, medicine, politics, law, philosophy, theology and climate change. The objective of this study is to examine the impact of using bioethics resources as teaching tool in the teaching of climate change at tertiary level. Approach: This is done through assessing the extent of bioethics knowledge acquired in the learning process and how bioethics principles affect respondents thinking and opinions. The research employs a qualitative analysis of the data that is collected through pre-and post-tests and from feedback solicited through discussions with respondents. Some 100 university undergraduate students participated in this study. Results: The findings reveal that through the use of bioethics resources in teaching climate change, respondents' showed increased comprehension of bioethics knowledge and greater appreciation of its principles. Conclusion: Therefore the study concludes that the use of bioethics resources can accentuate the importance of bioethics principles in the understanding and in the provision of ethical framework in dealing with climate changes issues and mitigation initiatives. This research finding can be a useful source of information for scholars and researchers developing teaching strategies using bioethics resources.
\end{abstract}

Key words: Bioethics principles, climate change, ethical framework, environment

\section{INTRODUCTION}

It has been widely said that the peril of climate change has very much to do with human actions and 'way of life'. Over the last century, with the rapid advent of science and technology, almost all aspects of human endeavor have experienced some level of change. Consumerism, consumption, population explosion and competition for resources have brought about many challenges to human, humanity and the environment (Moorthy and Sivapalan, 2010). These new developments have brought about new problems and ethical issues in the likes of environmental pollution, human and other species' livability, organ transplantation, genetic engineering and assisted reproductive technologies. Thus, the argument put forth in this study is that 'human-induced' problems of the environment requires 'ethical reasoning' in its mitigation efforts. Since this study addresses two main body of knowledge- 'climate change' and 'bioethics'-it is essential at this initial stage, to provide clear understanding on 'what and how' this study contributes to the existing body of knowledge in these fields.

Climate change is one of the most fundamental challenges ever to confront humanity. The United Nations Framework Convention on Climate Change (UNFCCC) in Article One and Two defined climate change as "change of climate which is attributed, directly or indirectly, to human activity that alters the compositions of the global atmosphere' (Ninnas, 2009). The massive deterioration of the environment through depletion of resources such as air, water and soil; the destruction of ecosystems and the extinction of wildlife, has greatly impacted on the survivability of the species living on the planet. Single handedly, climate change is the most fundamental issue to long-term global prosperity and the survival of humans as a species. This situation has been largely blamed on human's unending

Corresponding Author: Ravichandran Moorthy, School of History, Politics and Strategy, Faculty of Social Sciences and Humanities, University Kebangsaan Malaysia, 43000 Bangi, Selangor, Malaysia 
quests for development by exploiting natural resources to the point of no return. Driven by capitalist value systems, states and enterprises compete for natural resources to meet their production needs. Coupled with the consumption culture, modern societies have begun to consume much more than they need-absorbing large amount of goods and services made available in the market-thus depleting natural resources at an alarming rate. This situation brings about a host of other problems that affect humans, other species and mother Earth (Moorthy and Sivapalan, 2010).

In addition to the impact to the environment and the eco-systems, climate change has also human security ramifications-for example the UNFCCC and the Kyoto Protocol were adopted to mitigate the impact of the consequences of climate change and indirectly, to improve human security by education and public awareness (Ninnas, 2009; Brauch et al., 2009; Hamdi et al., 2009). Brauch (2005) posits that climate change has contributed to the expansion of the traditional narrow definition of international security, focusing more on environmental security. Thus, security does not only cover the security of the nations but has been extended to include other aspects of human wellbeing. The scarcity of natural resources like energy and water has resulted in states complete for these resources, as Strong (2001) puts it, "climate change is shaping up as the mother of all environmental battles and it will not be resolved quickly and easily'.

Having outlined the above concerns, scholars have come to acknowledge that adjusting the relationship between humans and nature is one of the most fundamental issues we face and must deal with today. With the increasing deterioration of ecological systems on which human beings rely and the aggravation of the environmental crisis, human beings have realized that they cannot rely on economic and judicial methods alone to solve the problems of environmental pollution and ecological imbalances. Humans must appeal to human beings' limitless internal ethical resources to provide the guiding principles to navigate through this dilemma-humans have to adopt an appropriate attitude towards nature and establish a new ethical relationship between human beings and nature (Have, 2006; Jaiswal, 2009; Focht and Abramson, 2009; Harrop, 2011; Chatterjee, 2011; Nelson, 2011; Buntod et al., 2010).

The central question addressed in this study is why bioethics is essential in climate change education. The answer to this question provides the readers the necessary understanding and comprehension of the moral dilemmas faced by humans in dealing with the environment, other species and the whole eco- systems. This study postulates that bioethics approach to teaching climate change will assist in the inculcation of ethical principles among students regarding climate change awareness and mitigation. Bioethics provide the platform for critical and responsible thinking on ethical principles that can aid decision making and foster the learning on how to balance different benefits, risk and duties. Bioethics is not about arriving at one specific correct solution to ethical problems but rather it suggests different choices made after ethical reflections (Macer, 2008). Based on this assertion, the study attempts to (i) gauge the extent of bioethics knowledge acquired from the learning session and (ii) to find out how bioethics principles regarding climate change affect respondents' thinking and opinions.

\section{MATERIALS AND MATHODS}

Location of study area: This study is based on a survey involving 100 second year international relations and political science students at Universiti Kebangsaan Malaysia (UKM). The teaching session was conducted at UKM. The session employed a case study on climate change as the primary instrument of analysis. The case study titled "Real, Urgent and Personal" was written in 2008 by group of writers for the Interchurch Bioethics Council (ICBC) New Zealand and was hosted on a website titled Bioethicsmatters (Interchurch Bioethics Council, 2008). However, for the purpose of this study, the case study was altered substantially to fit into the Malaysian 'worldview'. The twenty-page case study highlights numerous issues of climate change and its ethical implications. The duration of the teachinglearning session is approximately $90 \mathrm{~min}$.

Data collection and analysis: The data was collected through the use of a survey. Firstly, by comparing the results between the 'pre-test' and 'post-test'. Respondants were given two set of ten questions eachone before undergoing the learning exercise and the second test after the learning exercise. The questions were structured at the level of 'knowledge' and 'comprehension' based on Bloom taxonomy (Bloom, 1956; 2011; Lee, 1999). The questions were rephrased in post-test while still highlighting similar issues as in the pre-test. This is to gauge the extent of learning that has taken place after the completion of the learning exercise. The second set of data is derived through a feedback session conducted at the end of the learning session. Feedbacks were solicited based on questions posed by the researcher regarding their comprehension of the bioethics principles that manifests in the 
learning session. This is to gauge the level of understanding and appreciation of the respondents on the need for addressing climate change through an ethical framework.

\section{RESULTS AND DISCUSSION}

Knowledge gained: Table 1 illustrates respondents' test results based on pre and post-tests. The pre-test analysis shows that respondents have at least some basic level of knowledge regarding climate change. No respondents obtained all wrong answers-55\% of respondents obtained test scores of up to $40 \%$. This indicates that university students are exposed to the issues of climate change, although not being part of the curriculum of studies of Malaysian universities. However, the data does not show high score as only $25 \%$ of respondents scored between $61-100 \%$. This shows that while respondents have some background knowledge of the issue at hand, their level of knowledge can be termed as basic or rudimentary. A large percent of respondents were unable to respond correctly to questions regarding the ethical framework.

Meanwhile, the post-test scores illustrate that significant learning has taken place. In the pre-test scores, $55 \%$ of respondents were under $40 \%$ score mark. However, there is marked improvement in the post-test as no respondent scored below this mark. All respondents scored higher-which goes to indicate that the learning process has significantly enhanced respondents' understanding and comprehension regarding issues of climate changes and the need for ethical framework to deal with this problem.

The analysis shows major improvement in the 81$100 \%$ score category, with a marked increase from $15 \%$ in the pre-test to $65 \%$ in the post-test. This considerable jump indicates that after undergoing the learning process, the respondents, not only grasped the issues of climate change more firmly, they also manage to comprehend the ethical dimensions of the climate change debate.

Perception of appreciation of bioethics principles: This is a self-assessment exercise where the respondents were asked specific questions regarding their understanding and comprehension of bioethics principles. The answers were given based on the categories indicated in Table 2.

Table 1: Categories of Pre- and Post-test Analysis

\begin{tabular}{lcc}
\hline Categories & $\begin{array}{l}\text { Pre-test } \\
\text { Average } \% \\
\text { of respondents) }\end{array}$ & $\begin{array}{l}\text { Post-test } \\
\text { (Average \% } \\
\text { of respondents) }\end{array}$ \\
\hline No learning has taken place & & 0 \\
(0\% score) & 0 & 0 \\
Positive learning (below 20\% score) & 20 & 0 \\
Positive learning (21-40\% score) & 35 & 15 \\
Positive learning (41-60\% score) & 20 & 20 \\
Positive learning (61-80\% score) & 10 & 65 \\
Positive learning (81-100\% score) & 15 & 100 \\
Total & 100 & \\
\hline
\end{tabular}

Table 2: Self-assessment on bioethics principles

\begin{tabular}{|c|c|c|c|c|}
\hline \multirow[b]{2}{*}{ Statement of bioethics principles } & \multirow[b]{2}{*}{$\begin{array}{l}\text { Unaware of } \\
\text { such value }\end{array}$} & \multicolumn{3}{|c|}{ Categories in percentage } \\
\hline & & $\begin{array}{l}\text { Does not } \\
\text { affect my } \\
\text { thinking/opinion }\end{array}$ & $\begin{array}{l}\text { Marginally } \\
\text { affect my/ } \\
\text { opinion thinking }\end{array}$ & $\begin{array}{l}\text { Affect my } \\
\text { thinking/opinion }\end{array}$ \\
\hline $\begin{array}{l}\text { Human beings are the stewards of this world and } \\
\text { have the responsibility to care for all "creation. }\end{array}$ & 7 & 12 & 56 & 25 \\
\hline $\begin{array}{l}\text { Human is the only creation that has the ability to } \\
\text { think and plan-thus he has the duty of care for all. }\end{array}$ & 8 & 23 & 37 & 32 \\
\hline $\begin{array}{l}\text { In dealing with climate, we need to move away } \\
\text { from an anthropocentric or human-centred attitude. }\end{array}$ & 25 & 22 & 37 & 16 \\
\hline $\begin{array}{l}\text { Dire need to reduce demand on the earth's resources } \\
\text { now-so that future generation do not suffer. }\end{array}$ & 30 & 28 & 23 & 19 \\
\hline $\begin{array}{l}\text { People should change of life style to } \\
\text { reduce the burden on the environment. }\end{array}$ & 09 & 28 & 30 & 33 \\
\hline $\begin{array}{l}\text { Public advocacy is important to } \\
\text { mitigate affects of climate change. }\end{array}$ & 11 & 21 & 36 & 32 \\
\hline $\begin{array}{l}\text { Responsibility to put ethical } \\
\text { values ahead of financial values. }\end{array}$ & 17 & 17 & 45 & 21 \\
\hline $\begin{array}{l}\text { Encourage ethical investment, where the effects of these } \\
\text { investments are not harmful to the environment. }\end{array}$ & 15 & 15 & 35 & 35 \\
\hline $\begin{array}{l}\text { Environmental ethics proposes a moral relationship between } \\
\text { human beings and the environment and its non-human contents. }\end{array}$ & 35 & 15 & 30 & 20 \\
\hline $\begin{array}{l}\text { Global climate-change is an amalgamation of } \\
\text { environmental, cultural, theological and social issue. }\end{array}$ & 38 & 25 & 15 & 22 \\
\hline
\end{tabular}


Stewardship ethics: Statements one and two refer to the concept of environmental stewardship. The concept suggests that human should take the leadership role to take care of the environment and its inhabitants. Being the only species endowed with the ability to think and plan, humans are better suited to manage issues and crises with regards to the environment. In this study, the analysis shows that environmental stewardship 'marginally affects' (56\%) and 'affects' (25\%) respondents' thinking and opinions. The position is further substantiated in statement two, where similar categories register a total of $69 \%$ score. This indicates that respondents, after going through the learning process feel that human commitment and involvement through environmental stewardship is essential in mitigating climate change.

Anthropocentrism: It holds that the human being is at the centre of the worldview, of all earth and even the solar system and the cosmos. This concept maintains that everything non-human in the natural world should be considered ethically in terms of its instrumental value to human (Lights and Rolston, 2003; Lahiri, 2011). The analysis of statement nine shows that $37 \%$ of respondents feel that this concept marginally affect the thinking and opinion with regard to climate change. However, it should be noted that $25 \%$ are unaware of such concept and another $22 \%$ say that they are not affected. This figure reflects a lack of understanding of this concept as it was not extensively explained in the case study.

Survivability: Statement four suggests that in order to sustain the survivability of future generation, we would need to reduce our reliance on earth's scarce resources.

The analysis shows that $30 \%$ of the respondents are unaware of this principle and another $28 \%$ remained unaffected by this statement. One plausible reason this situation is that most respondents may have associated the issues of climate change with pollution caused by the use of fossil fuel-which in actual case only one part of the bigger picture. The concept of reduction has not been the norm of modern societies-consumerism and consumption has influenced our lifestyle for decadeshaving laid the foundation of the modern economy. As such, it is understandable why the respondents feel hesitant to subscribe to this principle. However, in statement five regarding the change of life style to reduce the burden on the environment, respondents seems to be more agreeable-registering 30\% score on marginal acceptance and $33 \%$ on acceptance. This finding may be extrapolated to show that, while they remained relatively unsure how to reduce the dependencies on earth's resources, they were more acceptable to the needs to alter lifestyle and practices that affects the environment.

Public advocacy: There seems to be greater acceptance from the respondents on the importance of engaging the masses in the fight against climate change. Some 32\% of respondents say that public advocacy has affected their thinking and opinions, with another $36 \%$ say that this principle has marginally affected their thinking as well. I would argue that the learning process has heightened their awareness on the importance of getting more people involved in this crusade.

Ethical investment: On the principle of ethical investment proposed by statements seven and eight. The analysis shows that there is a higher degree of acceptance of these values, with $21 \%$ of respondents agree that prioritising ethical values ahead of financial values in important to them, with another $45 \%$ felt marginally affected by this value. On the need to encourage investments that would not be harmful to the environment, some $35 \%$ respondents said that this value affects their thinking, with another 35\% being marginally affected. The scores on both statements seven and eight indicate that there is heighten level of awareness among respondents on the need to take more responsibility on the type of investments being undertaken- especially to ensure that these initiatives are not solely economicdriven without taking into account the environment.

Environmental ethics: It concerns human beings' ethical relationship with the natural environment. It also refers to the human beings' responsibility in safe guarding and preserving natural environment and in ensuring earth's resources remain adequate for future generations. The analysis shows that there is a substantial 38\% respondent is unaware of such a concept and another $15 \%$ say the precept does not affect them. One plausible reason for this situation is perhaps the case study is inundated with numerous environment concepts that required more thorough reading and more frequents learning processes for them to be properly grasped.

\section{CONCLUSION}

The study concludes that the level of knowledge acquisitions and awareness on ethical ramifications regarding climate change and bioethics have risen significantly after undergoing the learning process that uses bioethics resources as teaching tool. This implies that interactive learning by using bioethics resources on climate change is an effective teaching-learning tool, not 
only to increase knowledge acquisitions regarding the subject matter but also in the inculcation of ethical values related to climate change. For future research, it is recommended that scholars explore the vast repertoire of Eastern bioethics principles as alternative framework in dealing with climate change issues.

\section{REFERENCES}

Bloom, B.S., 1956. Taxonomy of Educational Objectives. 2nd Edn., Addison Wesley Publishing Company, New York. ISBN-10: 0582280109.

Bloom, T., 2011. In Learning and Teaching.

Brauch, H.G., 2005. Environment and Human Security. Freedom from Hazard Impact. InterSecTions, 2/2005. UNU-EHS, Bonn.

Brauch, H.G., J. Grin and C. Mesjasz, P. Kameri-Mbote and U.O. Spring, 2009. Facing Global Environmental Change: Environmental, Human, Energy, Food, Health and Water Security Concepts. 1st Edn., Springer, Berlin, ISBN: 3540684875, pp: 1586.

Buntod, P.C., P. Suksringam and A. Singseevo, 2010. Effects of learning environmental education on science process skills and critical thinking of mathayomsuksa 3 students with different learning achievements. J. Soc. Sci., 6: 60-63. DOI: 10.3844/jssp.2010.60.63

Chatterjee, D., 2011. Dynamic sustainabilities: technology, environment, social justice. J. Environ. Policy Plann., 13: 71-73. DOI: 10.1080/1523908X.2011.557899

Focht, W., and C.I. Abramson, 2009. The case for interdisciplinary environmental education and research. Am. J. Environ. Sci., 5: 124-129. DOI: 10.3844/ajessp.2009.124.129

Hamdi, M.R, Abu-Allaban, M, Al-Shayeb, A. Jaber, M and Momani, N.M. 2009. Climate change in Jordan: A comprehensive examination approach. Am. J. Environ. Sci., 5: 58-68. DOI: 10.3844/ajessp.2009.58.68
Harrop, S.R., 2011. Living In Harmony with Nature? Outcomes of the 2010 Nagoya Conference of the convention on biological diversity. J. Environ. Law, 23: 117-128. DOI: 10.1093/jel/eqq032

Have, H.T., 2006. Environmental Ethics and International Policy. UNESCO Publishing, Paris, ISBN: 9231040391, pp: 226.

Interchurch Bioethics Council, 2008. Real, Urgent and Personal: A Study Guide to Global Climate Change for Secondary Students and Teachers. Bioethicsmatters, New Zealand.

Jaiswal, S.K., 2009. Development or the environment. Am. J. Econ. Bus. Admin., 1: 257-262. DOI: 10.3844/ajebasp.2009.257.262

Lahiri, S., 2011. Assessing the environmental attitude among pupil teachers in relation to responsible environmental behavior: A leap towards sustainable development. J. Soc. Sci., 7: 33-41. DOI: $10.3844 /$ jssp.2011.33.41

Lee, V.S., 1999. Creating a blueprint for the constructivist classroom. National Teaching Learning Forum, 8:

Lights, A. and H. Rolston, 2003. Environmental Ethics: An Anthology. 1st Edn., Wiley-Blackwell Publishing, Oxford, ISBN: 0631222944, pp: 554.

Macer, D.R.J., 2008. Moral Games for Teaching Bioethics. UNESCO Chair in Bioethics, Israel.

Moorthy, R. and S. Sivapalan, 2010. Some Ethical Thoughts from the Indian Traditions. Eubios, J. Asian, Internat. Bioethics, 20: 180-183.

Nelson, G., 2011. Climate change treaty: Rough justice or no justice? Environ. Politics, 20: 284-289. DOI: 10.1080/09644016.2011.551035

Ninnas, Y.N., 2009. Human Security, Climate change and Small Islands. In: Facing Global Environmental Change, Brauch, H.G., J. Grin and C. Mesjasz, P. Kameri-Mbote and U.O. Spring (Eds.). Springer, Berlin.

Strong, M., 2001. Where on Earth are We Going? 1st Edn., Texere, New York, London, ISBN-10: 158799092X, pp: 431. 